\title{
Development of the Process for Whey Based Pineapple Beverage
}

\author{
Ashutosh Pandey*, Atul Anand Mishra, R.N. Shukla, \\ Praveen Kumar Dubey and Rahul Kumar Vasant
}

\begin{abstract}
Department of Food Process Engineering, Vaugh Institute of Agriculture Engineering and Technology, Sam Higginbottom University of Agriculture, Technology and Sciences, SHIATS University P.O Naini, Allahabad, U.P-211007, India
\end{abstract}

*Corresponding author

\section{A B S T R A C T}

\section{Keywords}

Whey, Pineapple juice, Whey beverage, Sensory Quality, Physicochemical qualities

Article Info

Accepted: 18 May 2019 Available Online: 10 June 2019
Whey is the aqueous (serum) protein of the milk. It compromises approximately $20 \%$ of the protein in milk, albumins and globulins, majority of lactose and the water soluble nutrients. The disposal of whey, the liquid remaining after the separation of milk fat and casein from the whole milk, is a major problem for the dairy industries, which demands simple and economic solutions. The usage of whey to valuable products could overcome the issue. Whey-based pineapple beverage was prepared by blending Pineapple juice with whey in different proportions such as 10:90, 20:80, 30:70, 40:60, 50:50 and $100 \mathrm{ml}$ juice as control, $3 \mathrm{~g}$ of sugar were fixed per $100 \mathrm{ml}$ of the beverage and analyzed for various physic- chemical and sensory characteristics for its overall acceptability. Acidity and TSS (Total Soluble Solids) content increased while $\mathrm{pH}$ decreased during storage. A significant decrease in ascorbic acid content was also observed during storage. The overall acceptability of the beverage was desirable up to 20 days of storage at refrigeration temperature. The study revealed that beverage prepared by blending the whey and Pineapple juice in proportion 30:70 (T3) \& sterilized at $85^{\circ} \mathrm{C}$ for $15 \mathrm{~min}$, was found better in almost all physic-chemical, microbial properties and sensory quality parameters as compared to other combination.

\section{Introduction}

The beverage industries have made significant progress during last several years in terms of production, but there is only a limited range of flavour available in India. Many types of artificial syrups, sherbets and soft drinks are more popular. At present fruit beverage is generally synthetic flavoured, bottled and sold in market. The beverages are not having any nutritive value. If these could be substituted with fruit juice and whey, these beverages will be more beneficial for the consumers.

The loss of body fluids from exertion, temperature and age gives rise to thirst, which is offset by drinking. The fluids are also accompanied by a loss of electrolytes, vitamins, lactates, amino acids and other organic components. A whey drink can 
replace much of the lost organics and in organics to the extracellular fluid. Whey, which is so rapidly assimilable, forms an ideal metabolic substrate. Whey drinks are light and refreshing but less acidic than fruit juices. The medicinal and nutritive value of sweet and acidic whey can be utilized with fruit juices/pulp and concentrates in developing acceptable long life beverages which appear to be the most obvious and logical avenue for utilizing the nutrients of whey into the human food chain. The manufacture of whey based beverage requires the mixing of appropriate fruit juices and minimally processed whey with selection of suitable stabilizers and acidulants to develop acceptable whey based fruit beverages (Singh et al., 2005). The key growth sector in utilization of whey for develop whey based beverage. Based on these facts the present investigation was conducted to develop a beverage from whey and pineapple juice.

Whey or Milk plasma is the liquid remaining after milk has been curdled and strained. It is a by-product of the manufacture of Paneer or cheese or casein and has several commercial uses. Acid whey (also known as "sour whey") is obtained during the making of acid type of cheese such as cottage cheese or Paneer. Whey is one of the most important byproducts obtained during the manufacturing of coagulated milk products like Paneer, cheese, channa etc. Whey is essentially milk depleted of milk fat and casein so that it is highly nutritious by- product. Nearly $70-90 \%$ of minerals present in milk pass on to whey.

Whey contains $5-7$ per cent total solids comprising of lactose 4.9 - 5.2 percent, protein about $0.3-0.8$ per cent, fat about 0.5 - 0.7 per cent and ash about $0.4-0.9$ per cent. Apart from these nutrients, whey also contains some of the important water soluble vitamins such as riboflavin, folic acid and other essential B complex vitamins in addition to amino acids such as valine, phenyl alanine, leucine and isoleucine. Even though the nutritional and therapeutic values of whey were know, whey was not being utilized probably due to the high cost of processing. Due to its high nutritional profiling whey can be used in beverages, geriatric and athletic foods (Baljeet et al., 2013).

In the light of nutritive profile of whey, importance of whey solids in the human food systems and popularity of beverages among Indian population, several attempts have been made to utilize whey in the production of refreshing beverage.

In India about 3 millions tons of whey is produced annually. Near about $40 \%$ of the raw whey is disposed in sewage which leads to serious environmental pollution. Therefore conservation of whey into fermented or nonfermented beverages is one of the most attractive avenues for the utilization of whey for human consumption.

Pineapple (Ananas comosus), belongs to the family Bromeliaceae, some of the pineapple varieties are Giant Kew, Queen, Mauritius, Jaldoop etc. Pineapple is a rich source of polyphenolic compounds (Baljeet et al., 2013). Antioxidants offer numerous health benefits such as anticancerous, antidiabetic and antihypertensive effects. $\mathrm{pH}$ of pineapple juice ranges between 3 to 4, which is lower than the isoelectric point of $\beta$-lactoglobin and lower pH.increases energy barrier for unfolding of the proteins, which hinders the non-covalent (disulphide interactions) bonding. Such noncovalent interactions are significant contributors for whey protein aggregation and hence can lead to colloidal unstability of whey beverages. Thus, use of pineapple juice in particular for the production of a whey-based beverage can be a good option for a shelf stable beverage with high nutraceutical potential. 
Pineapple is a rich source of vitamin $\mathrm{C}$ as well as other vitamins and fiber. Pineapple stimulates digestion and the proper performance of the small intestine and kidneys; it helps in detoxification, normalizes colonic flora, helps in hemorrhoid alleviation, and prevents and corrects constipation (due to the fiber content of the pulp). It has been used to heal colds, mouth, throat and bronchial infections. Cooked peel cleans blood and alleviates swellings. Juice helps to cure cystitis, and fevers (www.peru.com/ gastronomia/docs2/). Lightly boiled ground pineapple can be used to clean infected wounds because it eliminates dead tissues, not affecting live tissue, acts as disinfectant and accelerates cicatrisation.

In pineapple beverage the ascorbic acid content showed significant decrease during 20 days of storage. The reduction in ascorbic acid content might be due to oxidation because of the presence of residual oxygen in glass bottles and this reduction can be minimized by eliminating oxygen during filling. The overall quality and acceptability of pineapple was highest among all.

But this quality and acceptability of juice decreases slightly with increase in storage period due to decreasing in color, flavor, taste and texture. The decrease in organoleptic rating might be due to decrease in ascorbic acid content.

Many attempts have been done on utilization of whey in the formulation of various dairy products but, still there is a lot of scope to explore the possibilities for its utilization in beverage industries.

Now a days Indian dairy industries looking for new product ideas and technologies to meet the consumer's requirements and to increase the profitability of the products as well as value added whey based functional products.

\section{Materials and Methods}

\section{Source of material and sample preparation}

The various raw materials used for the preparation of whey based pineapple beverage were obtained for the local market of Allahabad.

\section{Chemical for whey based beverage preparation}

\section{Sugar}

It is an informal term for a class of edible crystalline substance, mainly sucrose, lactose and fructose characterized by sweet flavour. In food sugar almost exclusively refers to sucrose, which primarily comes from sugar cane and sugar beet. Sugar gives sweetness to the product, and also helps in increasing the shelf life of the product. We use the powdered sugar for the beverage to facilitate homogeneous mixing.

\section{Sodium benzoate}

It's added to the soft drinks as a preservative and antimicrobial agent. It's also known as E211 is a major ingredients in soft drinks.

\section{Tri sodium citrate}

It is used as a buffering agent for $\mathrm{pH}$ control to help regulate tartness or to control acidity.

\section{Procurement of pineapple}

\section{Preparation of pineapple juice}

Flow chart preparation of pineapple juice is given in Figure 1.

\section{Preparation of whey}

The flow chart for Pretreatments of whey is given in Figure 2. 


\section{Chemical analysis of whey}

\section{Acidity of whey}

Acidity of whey was determined as per (BIS: 1479, Part-I, 1960) by titrating $10 \mathrm{ml}$ of whey against the standard $\mathrm{N} / 10 \mathrm{NaOH}$ solution using phenolphthalein as an indicator and expressed as per cent lactic acid.

$\%$ Titrable acidity $=\frac{9 \mathrm{NV}}{W}$

\section{pH of whey}

The $\mathrm{pH}$ of whey was determined by using pocket size digital $\mathrm{pH}$ meter (Double junction $\mathrm{pH}$ tester 10, Eutech Instruments, Oakton Instruments).

\section{Fat of whey}

The whey was analyzed for per cent fat (BIS: 1224, Part-1 1977) using modified Gerber Centrifuge method.

\section{Packaging material}

\section{Glass and plastic bottles}

Murlider et al., (2009) Glass bottles are used for storing the beverage. The glass bottles were chosen for the product visibility and acceptance. The amount of product packed in each bottle is $100 \mathrm{ml}$ and the dimensions or size of the bottles used was standard.

\section{Thermal processing}

The standardized product is thermally processed at different time temperature combinations and the process schedule is given in Table 1.

\section{Method of preparation}

Whey based pineapple beverage was prepared by referring to the method used by Gagrani et al., (1987), Singh et al., (1994), Sahu (2003) and Naik et al., (2009). The whey obtained is pasteurized at $90^{\circ} \mathrm{C}$ and is chilled with no holding and then stored in the bottles for further use. The bottles are thawed if necessary for the further use. Pasteurized whey is then filtered using muslin cloth. During the preparation of beverage sugar powder were added in whey and Whey was heated to dissolve sugar. Then after the rest of whey is mixed with the pineapple juice and the premix and the preservative are added to it, the brix is lowered to almost $10^{\circ} \mathrm{Brix}$. Then the beverage is transferred to sterilized glass bottles, which are again sterilized (at $80^{\circ} \mathrm{C}$, $85^{\circ} \mathrm{C}, 90^{\circ} \mathrm{C}, 95^{\circ} \mathrm{C}$ for 15 minutes) by using water bath then; it is then cooled and stored. Flow chart for preparation of whey based pineapple beverage given in Figure 3.

\section{Formulation}

Table.2 Standardisation of whey based pineapple beverage

\begin{tabular}{|c|c|c|}
\hline TREATMENT & $\begin{array}{c}\text { WHEY } \\
(\mathbf{m l})\end{array}$ & PINEAPPLEJUICE (ml) \\
\hline T0 & 00 & 100 \\
\hline T1 & 10 & 90 \\
\hline T2 & 20 & 80 \\
\hline T3 & 30 & 70 \\
\hline T4 & 40 & 60 \\
\hline T5 & 50 & 50 \\
\hline
\end{tabular}

\section{Physicochemical analysis}

The chemical analysis of fresh and stored products was carried out at every 5 days interval during the investigation.

\section{Determination of total soluble solids (TSS)}

The TSS value is defined as the amount of sugar, protein and soluble minerals etc. present in fruit beverages. For measuring TSS 
in ${ }^{\circ}$ Brix, a hand refractometer was used. The refractometer was calibrated by placing a few drops of distilled water on the prism in the specimen chamber of tile refractometer. The distilled water reading should be zero. For determining the TSS, a drop of sample is placed on the prism and the ${ }^{\circ}$ Brix of dry substance in it read directly. The refractometer was directed towards light and observed through eyepiece to see the boundary line separating the light and dark areas of the images on the screen given with the calibrated scale. The number given parallel to this separating line gives the TSS of the sample in ${ }^{\circ}$ Brix.

\section{Determination of titrable acidity}

Titrable acidity was determined by titration method as suggested by Ranganna (2002). Acidity of juice was analyzed by titrating a known volume of sample $(10 \mathrm{ml})$ against the standard $0.1 \quad \mathrm{~N} \quad \mathrm{NaOH}$ solution using phenolphthalein as an indicator and it was expressed in terms of citric acid.

- $\quad 10 \mathrm{ml}$ of the prepared solution of each sample was taken in a conical flask.

- 3-4 drops of phenolphthalein was added as an indicator.

- $\quad$ Titrated it against with $0.1 \mathrm{~N} \mathrm{NaOH}$.

- At the end point of titration a faint pink colour persist for few seconds.

\section{Calculation}

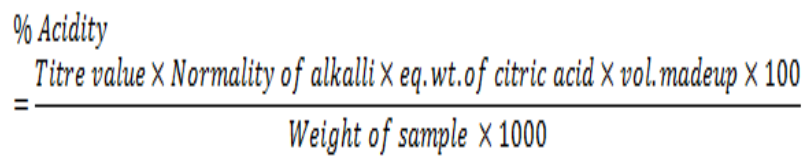

* The eq. wt. of citric acid is 64 .

\section{Determination of $\mathbf{p H}$}

The $\mathrm{pH}$ of pineapple juice was measured by using pocket size digital $\mathrm{pH}$ meter (Double junction $\mathrm{pH}$ tester 10, Eutech Instruments, Oakton Instruments).

\section{Determination of total sugar}

The sugar content of pineapple juice was determined by Lane and Eyon's method as suggested by Ranganna (2002).

Twenty five gram of pulp was weighted accurately in $200 \mathrm{ml}$ conical flask and was diluted with $100 \mathrm{ml}$ luke-warm water (35$45^{\circ} \mathrm{C}$ ) and neutralized it with $1 \mathrm{~N} \mathrm{NaOH}$. The content of the flask were mixed thoroughly. For the precipitation of protein in the juice, neutral lead acetate and potassium oxalate solution was used as precipitant.

After precipitation, the content was filtered through filter paper into a $200 \mathrm{ml}$ graduated flask. The precipitate and the paper were washed thoroughly with hot water and the washings were collected in the flask. The flask and contents were cooled and the volume was made up to mark and filtrate was used for estimation of reducing sugar and total sugar.

Filtrate obtained was hydrolyzed by boiling $25 \mathrm{ml}$ of filtrate with $5 \mathrm{ml}$ of 54 per cent HCI for 10 minutes. After cooling the contents were neutralized with $1 \mathrm{~N} \mathrm{NaOH}$ solution. The volume was titrated against $5 \mathrm{ml}$ of each of Fehling's solution A and B and per cent total sugar was determined as under:

\% Total sugar as invert sugar $=\frac{\text { Factor for Fehling's solution as invert sugar } x 4}{\text { Titer } 4}$

\section{Determination of ascorbic acid}

The ascorbic acid was determined using method suggested by Ranganna (2002) titrating a known volume of sample with 2,6dichlorophenol indophenol dye using metaphosphoric acid as stabilizing agent. 20 
$\mathrm{ml}$ of sample was taken and made to $100 \mathrm{ml}$ with $3 \%$ HPO3 and filtered using filter paper. 2-10 ml aliquot with HPO3 extracts of the sample and was titrated with the standard dye to a pink colour at the end point and percent ascorbic acid was determined as under.

Ascorbic acid mg $/ \mathrm{l} 00 \mathrm{~g}=\frac{\text { Titer } \times \text { Dye Factor } \times \text { Vol. Made up } x 100}{\text { Aliquot of extract taken } x \text { Vol. of sample }}$

\section{Microbiological analysis}

\section{Yeast and mold count}

\section{Media}

Ringers solution

Potato dextrose agar

\section{Procedure}

1. Labeled 5 test tubes as $10^{-1}, 10^{-2}, 10^{-3}$, $10^{-4}$ and $10^{-5}$ respectively.

2. Taken $9 \mathrm{ml}$ of ringer solution in each test tube.

3. Added $1 \mathrm{ml}$ of the sample (beverage) to test tube labeled as $10^{-1}$.

4. Taken $1 \mathrm{ml}$ of the sample from $10^{-1}$ dilution and pour the sample to $10^{-2}$ dilution. Continue the process of serial till the dilution has reach unto $10^{-5}$

5. Labeled five Petridish each for $10^{-1}, 10^{-2}$, $10^{-3,} 10^{-4}$ and $10^{-5}$

6. Pour $1 \mathrm{ml}$ of diluted sample from 10-1 from dilution in to four Petridish each.

7. Repeated the sample for $10^{-2}, 10^{-3}, 10^{-4}$ and $10^{-5}$.

8. Poured sterilized melted potato dextrose agar in each Petridish.
9. Incubated at $37^{\circ} \mathrm{C}$ for $24-48 \mathrm{hrs}$.

10. Then the colonies were counted and average was calculated.

\section{Standard plate count}

The microbiological analysis i.e. standard plate count test was done by using standard procedure laid down in I.S. 1947 PART 3.

\section{Statistical analysis}

The experiment was conducted by adopting completely randomized design the data recorded during the course of investigation were statistically analyzed by the Analysis of variance- Two way classification or single factor ANOVA'. This technique was developed by Dr. R. A. Fisher in 1923 gives an appropriate method capable of analyzing the variation of population variance. The significant effect of treatment was judged with the help of ' $F$ ' (variance ratio). Calculated $\mathrm{F}$ value was compared with the table value of $\mathrm{F}$ at $5 \%$ level of significance. If calculated value exceeded the table value the affect was considered to the significant. The significance of the study was tested $5 \%$ level.

\section{Sensory evaluation}

Sensory evaluation of control and experimental beverages were done by a panel of five judges using a nine point hedonic scale.

The judges were from the Department of Food Process Engineering. The data were analyzed of variances to compare sensory rating of the samples. The panel of judges graded the codes of the samples on a 9 point hedonic scale with corresponding descriptive terms ranging from 9' like extremely' to 1 ' dislike extremely'. 


\section{Results and Discussion}

The research project entitled "Development of the process for whey based pineapple beverage". The experiments were conducted to study the preparation, process development, quality evaluation and shelf life studies of whey based pineapple beverage. Studies on quality were based on physiochemical characteristics (i.e. TSS, $\mathrm{pH}$, vitamin C content, Total Sugar content, and Titrable Acidity of beverage) and sensory characteristics, which were determined for stored samples.

The characteristics of whey based pineapple beverage were influenced by storage of environmental condition and chemical constituents of beverage. The storage studies were conducted at the interval of 5 and 10 days up to 20 days. The results of the study are being presented and discussed in following section.

Process development for whey based pineapple beverage

In the present investigation an attempt were made to develop the process for whey based pineapple beverage by taking different percentage of pineapple juice and whey.

The beverages obtained were filtered and filled into glass bottles $(100 \mathrm{ml})$ followed by sealing of bottles by crown cork, and sterilized at Four levels of sterilization Temperature viz., $\left(75^{\circ} \mathrm{C}, 80^{\circ} \mathrm{C}, 85^{\circ} \mathrm{C}, 90^{\circ} \mathrm{C}\right)$ for 15 minutes. The formulated beverages neither contained any artificial flavoring, coloring, nor thickening agents. Chemical preservative and stabilizer was added during preparation of whey based pineapple beverage.

Three replications of each experiment were carried out. Physico -chemical and sensory qualities of beverages were analyzed for fresh as well as stored samples at an interval of 5 days.

Storage study was carried out for a period of 20 days to access the overall acceptability of beverages and to know the effect of storage period on acidity, total soluble solid (TSS), $\mathrm{pH}$, total sugar, ascorbic acid and Microbial studies, sensory characteristic of the formulated beverages.

Evaluation of the physicochemical and sensory characteristic of developed whey based pineapple beverage

Effect of thermal processing $\left(7^{\circ} \mathrm{C}, 80^{\circ} \mathrm{C}\right.$, $85^{\circ} \mathrm{C}$ and $90^{\circ} \mathrm{C}$ for $\left.15 \mathrm{~min}\right)$, on physicochemical characteristics of whey based pineapple beverage during storage

Whey Based pineapple beverages were prepared. The products were evaluated for TSS, $\mathrm{pH}$, acidity, ascorbic acid and total sugar to evaluate the quality of the products. The results are summarized in the following paragraphs and discussed subsequently.

\section{Effect on total soluble solids (TSS)}

TSS of each preparation of beverages at different period of storage at refrigerated temperature is presented in Table 1. Data given in the Table 1 indicates that the treatment have significant effect on the TSS of the beverages. The effect of thermal processing did not have any influence on the TSS of whey beverage on 0th day as well as on 20th day. All the preservatives added whey beverage show significance difference.

As the storage period increases the TSS content increased in control as well as beverage, at the 20th day of storage TSS have the highest value. 
There was none significance difference at 0 th and 05 th day but it was found significance at 05 th and 20th day of storage.

Data indicated that gradual increase in total solid in all the levels of treatment because of gradual hydrolysis of polysaccharides presents in beverages during storage. The highest value of TSS was recorded to be
14.980 Brix at the end of 20 days of storage when beverages were stored at refrigerated temperature.

Increase in TSS might be due to the solubilization of insoluble portion of the products due to presence of acids (ascorbic and citric acid) during storage as reported by Sethi (1992).

\begin{tabular}{|c|c|c|c|c|c|c|c|c|c|c|c|c|c|c|c|c|}
\hline & \multicolumn{4}{|c|}{ O DAYS } & \multicolumn{4}{|c|}{10 DAYS } & \multicolumn{4}{|c|}{15 DAYS } & \multicolumn{4}{|c|}{20 DAYS } \\
\hline & $7^{\circ} \mathrm{C}$ & $80^{\circ} \mathrm{C}$ & $85^{0} \mathrm{C}$ & $90^{\circ} \mathrm{C}$ & $7^{\circ} \mathrm{C}$ & $80^{\circ} \mathrm{C}$ & $85^{0} \mathrm{C}$ & $90^{\circ} \mathrm{C}$ & $75^{\circ} \mathrm{C}$ & $80^{\circ} \mathrm{C}$ & $85^{0} \mathrm{C}$ & $90^{0} \mathrm{C}$ & $7^{\circ} \mathrm{C}$ & $80^{\circ} \mathrm{C}$ & $85^{0} \mathrm{C}$ & $90^{\circ} \mathrm{C}$ \\
\hline T0 & 10.23 & 10.32 & 10.21 & 10.00 & 11.05 & 11.17 & 10.35 & 10.64 & 12.18 & 11.23 & 10.85 & 11.15 & 13.14 & 12.18 & 11.11 & 11.57 \\
\hline T1 & 11.06 & 11.58 & 10.40 & 10.28 & 11.55 & 11.88 & 11.12 & 10.42 & 11.80 & 12.06 & 11.48 & 11.22 & 12.21 & 12.40 & 11.55 & 11.41 \\
\hline $\mathbf{T 2}$ & 11.23 & 11.69 & 11.12 & 10.88 & 11.84 & 11.94 & 11.32 & 11.18 & 12.14 & 12.12 & 11.63 & 11.58 & 12.48 & 12.36 & 11.75 & .17 \\
\hline T3 & 11.40 & 11.22 & 11.23 & 11.12 & 11.80 & 11.54 & 11.54 & 11.44 & 12.00 & 12.15 & 11.74 & 11.88 & 12.32 & 12.31 & 11.82 & 12.39 \\
\hline T4 & 11.55 & 12.08 & 11.76 & 11.36 & 11.87 & 12.22 & 12.28 & 11.62 & 12.14 & 12.35 & 12.48 & 12.16 & 12.35 & 12.55 & 12.65 & 12.48 \\
\hline T5 & 12.11 & 12.22 & 12.00 & 12.19 & 12.22 & 12.40 & 12.29 & 12.88 & 12.38 & 12.55 & 12.70 & 13.06 & 12.47 & 13.00 & 12.95 & 13.31 \\
\hline
\end{tabular}

Barwal et al., (2005) also observed an increase in the TSS of the developed bitter gourd RTS drink during storage. Increase in TSS was also reported by Yadav et al., (2010) in whey based banana herbal beverage.

\section{Effect of thermal processing on Titrable acidity of beverage during storage period}

Titrable acidity of beverages at different period of storage at refrigerated temperature is presented in Table 1 .

The effect of storage period on Titrable acidity of control $\mathrm{T} 0$ and experimental sample $\mathrm{T} 1, \mathrm{~T} 2, \mathrm{~T} 3, \mathrm{~T} 4$ and $\mathrm{T} 5$ at 5 days interval during storage is shown in below table. On evaluation of result, it was found that there was increase in acidity of the juice sample as presented in figure 4. On optimized evaluation of the result during storage, it was found that the titrable acidity increases with increase in storage period. The increase in acidity might be due to the accelerated degradation of pectin substances or due to formation of organic acids like ascorbic acid and conversion of lactose to lactic acid also.

\begin{tabular}{|c|c|c|c|c|c|c|c|c|c|c|c|c|c|c|c|c|}
\hline & \multicolumn{4}{|c|}{ O DAYS } & \multicolumn{4}{|c|}{10 DAYS } & \multicolumn{4}{|c|}{15 DAYS } & \multicolumn{4}{|c|}{20 DAYS } \\
\hline & $7^{\circ} \mathrm{C}$ & $80^{\circ} \mathrm{C}$ & $85^{\circ} \mathrm{C}$ & $90^{\circ} \mathrm{C}$ & $7^{\circ} \mathrm{C}$ & $80^{\circ} \mathrm{C}$ & $85^{\circ} \mathrm{C}$ & $90^{\circ} \mathrm{C}$ & $7^{\circ} \mathrm{C}$ & $80^{\circ} \mathrm{C}$ & $85^{\circ} \mathrm{C}$ & $90^{\circ} \mathrm{C}$ & $75^{\circ} \mathrm{C}$ & $80^{\circ} \mathrm{C}$ & $85^{\circ} \mathrm{C}$ & $90^{\circ} \mathrm{C}$ \\
\hline T0 & 0.86 & 0.87 & 0.68 & 0.68 & 080 & 0.88 & & 15 & 88 & 080 & .77 & 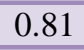 & 4 & 91 & 31 & .88 \\
\hline T1 & 81 & 0.8 & 0.6 & .6 & & 0.8 & 0.69 & & .84 & 84 & 72 & 7 & .87 & 86 & 8 & 81 \\
\hline T2 & 73 & 0.75 & 50 & 061 & 74 & 0.77 & 67. & 0. & 0.76 & 0.79 & 59 & 8 & 0.82 & .84 & .76 & 0.74 \\
\hline T3 & 68 & 0.71 & 0.57 & 0.58 & 0.71 & 0.77 & 0.64 & 0.6 & 0.72 & 0.78 & 0.64 & 0.71 & 0.74 & 0.82 & 0.66 & 0.81 \\
\hline T4 & 0.65 & 0.65 & 0.55 & 0.55 & 0.67 & 0.74 & 0.62 & 0.62 & 0.68 & 0.76 & 0.63 & 0.64 & 0.69 & 0.78 & 0.68 & 0.72 \\
\hline T5 & 0.54 & 0.61 & 0.52 & 0.51 & 0.56 & 0.64 & 0.59 & 0.59 & 0.57 & 0.65 & 0.61 & 0.61 & 0.59 & 0.68 & 0.64 & 0.67 \\
\hline
\end{tabular}

Effect of thermal processing on $\mathrm{pH}$ value of beverage during storage period

The effect of different treatment and storage period on $\mathrm{pH}$ of experimental sample $\mathrm{T} 0, \mathrm{~T} 1$, T2, T3, T4 and T5 after interval during storage is shown in below table. The effect of different treatment and storage period on $\mathrm{pH}$ 
of control and experimental sample during storage is shown in below table on evaluation of result it was found that there was decrease in $\mathrm{pH}$ of the Beverage sample with increase in titrable acidity as shown in figure 4. The decrease in $\mathrm{pH}$ was due to increase in acidity i.e. they are inversely proportional to each other.

\begin{tabular}{|c|c|c|c|c|c|c|c|c|c|c|c|c|c|c|c|c|}
\hline \multirow[t]{2}{*}{ sample } & \multicolumn{4}{|c|}{ O DAYS } & \multicolumn{4}{|c|}{10 DAYS } & \multicolumn{4}{|c|}{15 DAYS } & \multicolumn{4}{|c|}{20 DAYS } \\
\hline & ${ }^{75^{\circ} \mathrm{C}}$ & $80^{\circ} \mathrm{C}$ & $85^{\circ} \mathrm{C}$ & $90^{\circ} \mathrm{C}$ & $75^{\circ} \mathrm{C}$ & $80^{\circ} \mathrm{C}$ & $85^{0} \mathrm{C}$ & $90^{\circ} \mathrm{C}$ & $7^{\circ} \mathrm{C}$ & $80^{\circ} \mathrm{C}$ & $85^{\circ} \mathrm{C}$ & $90^{\circ} \mathrm{C}$ & ${ }^{75^{\circ}} \mathrm{C}$ & $80^{\circ} \mathrm{C}$ & $85^{0} \mathrm{C}$ & $90^{\circ} \mathrm{C}$ \\
\hline T0 & 4.56 & 4.61 & 4.55 & 4.63 & 4.52 & 4.48 & 4.49 & 4.53 & 4.45 & 4.41 & 4.42 & 4.47 & 4.38 & 4.32 & 4.36 & 4.31 \\
\hline T1 & 4.44 & 4.45 & 4.52 & 4.58 & 4.37 & 4.38 & 4.45 & 4.49 & 4.32 & 4.35 & 4.39 & 4.44 & 4.28 & 4.29 & 4.31 & 4.32 \\
\hline T2 & 4.37 & 4.41 & 4.48 & 4.52 & 4.29 & 4.34 & 4.42 & 4.43 & 4.25 & 4.28 & 4.37 & 4.38 & 4.21 & 4.21 & 4.29 & 4.29 \\
\hline T3 & 4.31 & 4.38 & 4.43 & 4.48 & 4.21 & 4.28 & 4.32 & 4.36 & 4.17 & 4.23 & 4.26 & 4.28 & 4.11 & 4.18 & 4.18 & 4.19 \\
\hline T4 & 4.26 & 4.32 & 4.38 & 4.42 & 4.18 & 4.22 & 4.26 & 4.32 & 4.11 & 4.16 & 4.22 & 4.26 & 4.06 & 4.09 & 4.15 & 4.18 \\
\hline T5 & 4.21 & 4.22 & 4.33 & 4.38 & 4.12 & 4.11 & 4.23 & 4.26 & 4.05 & 4.08 & 4.18 & 4.16 & 3.91 & 3.84 & 4.09 & 4.06 \\
\hline
\end{tabular}

Effect of Thermal processing on Ascorbic Acid content of beverage during storage period

The effect of different treatment and storage period on vitamin $\mathrm{C}$ content of control $\mathrm{T} 0$, and experimental $\mathrm{T} 1, \mathrm{~T} 2, \mathrm{~T} 3 \mathrm{~T} 4$ and $\mathrm{T} 5$ sample at 5th day interval during storage period is shown in below table. The effect of storage period on ascorbic acid of beverage shown in Table. It can be seen from the
Table that the content of ascorbic acid decreased gradually in each sample over a period of 20 days storage for all the treatments T0, T1, T2, T3, T4 and T5 along with control T0. This decrease in ascorbic acid may be due to increase in acidity content in the stored product. It is due to the degradation of ascorbic acid to carbolic acid under acidic condition.

\begin{tabular}{|c|c|c|c|c|c|c|c|c|c|c|c|c|c|c|c|c|}
\hline \multirow[t]{2}{*}{ sample } & \multicolumn{4}{|c|}{ 0 DAYS } & \multicolumn{4}{|c|}{10 DAYS } & \multicolumn{4}{|c|}{15 DAYS } & \multicolumn{4}{|c|}{20 DAYS } \\
\hline & $75^{\circ} \mathrm{C}$ & $80^{\circ} \mathrm{C}$ & $85^{\circ} \mathrm{C}$ & $90^{\circ} \mathrm{C}$ & ${ }^{75^{\circ} \mathrm{C}}$ & $80^{\circ} \mathrm{C}$ & $85^{\circ} \mathrm{C}$ & $90^{\circ} \mathrm{C}$ & ${ }^{75^{\circ}} \mathrm{C}$ & $80^{\circ} \mathrm{C}$ & $85^{\circ} \mathrm{C}$ & $90^{0} \mathrm{C}$ & $7^{\circ} \mathrm{C}$ & $80^{\circ} \mathrm{C}$ & $85^{\circ} \mathrm{C}$ & $90^{\circ} \mathrm{C}$ \\
\hline T0 & 5.69 & 5.52 & 5.23 & 5.11 & 5.61 & 5.48 & 5.17 & 5.05 & 5.58 & 5.46 & 5.16 & 5.03 & 5.57 & 5.44 & 5.14 & 5.00 \\
\hline T1 & 5.65 & 5.49 & 5.20 & 5.09 & 5.58 & 5.45 & 5.15 & 5.03 & 5.57 & 5.44 & 5.14 & 5.01 & 5.56 & 5.43 & 5.12 & 4.98 \\
\hline $\mathbf{T} 2$ & 5.60 & 5.45 & 5.17 & 5.05 & 5.54 & 5.40 & 5.12 & 4.98 & 5.52 & 5.38 & 5.10 & 4.96 & 5.51 & 5.37 & 5.09 & 4.95 \\
\hline T3 & 5.57 & 5.41 & 5.14 & 5.01 & 5.50 & 5.38 & 5.10 & 4.95 & 5.51 & 5.37 & 5.08 & 4.92 & 5.48 & 5.35 & 5.06 & 4.90 \\
\hline T4 & 5.51 & 5.37 & 5.11 & 4.98 & 5.48 & 5.33 & 5.07 & 4.92 & 5.46 & 5.31 & 5.06 & 4.90 & 5.44 & 5.30 & 5.05 & 4.88 \\
\hline T5 & 5.40 & 5.32 & 5.08 & 4.92 & 5.45 & 5.29 & 5.05 & 4.88 & 5.43 & 5.27 & 5.03 & 4.86 & 5.41 & 5.25 & 5.00 & 4.85 \\
\hline
\end{tabular}

According to the Blasco et al, (2004), there are two different rates of ascorbic acid degradation observed during the heating process: an aerobic degradation followed by an anaerobic degradation.

In beginning of the heating process oxygen in abundance takes place. With prolonged time of heating the atmosphere in bottle becomes saturated with vapour, so that the oxygen concentration is minimal and the ascorbic acid is degraded anaerobically. Similar results have also been reported by Sirohi et al., (2005) and Naik et al., (2009).

\section{Effect of thermal processing on Total sugar content of beverage during storage period}

Total sugar content of each preparation of beverages at different period of storage is presented in below Table. 
The results obtained during investigation are in agreement with Krishnaveni et al., (2001) and Kumar and Manimegalai (2005) observed a decrease in the total sugars content during storage of whey based papaya RTS and Jack fruit RTS beverage respectively.

However the storage temperature in these studies is at refrigerated condition. However Sirohi et al., (2005) and Ritika et al., (2010) observed no variation in the total sugars content during whey based mango herbal and whey based banana herbal respectively.

The decrease in total sugar content in the present investigation may be due to the storage which could have favoured the maillard reaction and other chemical reaction of sugars with acids during the storage resulting in decrease in total sugar content.

\begin{tabular}{|c|c|c|c|c|c|c|c|c|c|c|c|c|c|c|c|c|}
\hline \multirow[t]{2}{*}{ Sample } & \multicolumn{4}{|c|}{ O DAYS } & \multicolumn{4}{|c|}{10 DAYS } & \multicolumn{4}{|c|}{15 DAYS } & \multicolumn{4}{|c|}{20 DAYS } \\
\hline & $75^{\circ} \mathrm{C}$ & $80^{\circ} \mathrm{C}$ & $85^{\circ} \mathrm{C}$ & $90^{\circ} \mathrm{C}$ & $75^{\circ} \mathrm{C}$ & $80^{\circ} \mathrm{C}$ & $85^{\circ} \mathrm{C}$ & $90^{\circ} \mathrm{C}$ & $75^{\circ} \mathrm{C}$ & $80^{\circ} \mathrm{C}$ & $85^{\circ} \mathrm{C}$ & $90^{\circ} \mathrm{C}$ & $75^{\circ} \mathrm{C}$ & $80^{\circ} \mathrm{C}$ & $85^{\circ} \mathrm{C}$ & $90^{0} \mathrm{C}$ \\
\hline T0 & 8.46 & 8.74 & 8.96 & 8.88 & 8.43 & 8.72 & 8.95 & 8.86 & 8.43 & 8.72 & 8.96 & 8.85 & 8.41 & 8.69 & 8.92 & 8.84 \\
\hline T1 & 8.43 & 8.71 & 8.92 & 8.84 & 8.41 & 8.68 & 8.90 & 8.83 & 8.39 & 8.68 & 8.88 & 8.82 & 8.38 & 8.66 & 8.87 & 8.78 \\
\hline $\mathbf{T} 2$ & 8.41 & 8.68 & 8.82 & 8.81 & 8.39 & 8.65 & 8.80 & 8.89 & 8.38 & 8.65 & 8.88 & 8.88 & 8.36 & 8.65 & 8.85 & 8.85 \\
\hline T3 & 8.39 & 8.65 & 8.77 & 8.78 & 8.36 & 8.63 & 8.75 & 8.76 & 8.36 & 8.61 & 8.74 & 8.75 & 8.35 & 8.58 & 8.70 & 8.72 \\
\hline T4 & 8.36 & 8.61 & 8.72 & 8.74 & 8.35 & 8.56 & 8.69 & 8.72 & 8.34 & 8.56 & 8.68 & 8.71 & 8.32 & 8.55 & 8.67 & 8.67 \\
\hline T5 & 8.32 & 8.58 & 8.68 & 8.71 & 8.29 & 8.55 & 8.66 & 8.68 & 8.29 & 8.52 & 8.65 & 8.67 & 8.26 & 8.49 & 8.64 & 8.65 \\
\hline
\end{tabular}

Effect of thermal processing on the sensory characteristics of whey based pineapple beverage during storage period

Freshly prepared beverages were subjected to sensory evaluation using 9 point hedonic scale by the panel of five judges. The scores obtained by the different samples on different sensory characteristics are presented in below Table. Data presented in table are the average of four replications. The evaluated sensory characteristics were color and appearance, flavor, mouth feel and overall acceptability of the samples. It can be seen from below table that the T3 beverage prepared with the addition of $70 \%$ juice and $30 \%$ whey scored highest (8.55) for overall acceptability. Increase in the whey more than $40 \%$ reduces the sensory score for Mouth feel and Overall acceptability in to gives bitter flavor. This may be due to the development of bitterness and pungent smell in the beverage as and when quantity of whey was increased Sensory evaluation of beverage is given in Figure 5.

\begin{tabular}{|l|l|l|l|l|l|l|}
\hline Sensory Evaluation card & & & \\
\hline Treatment & Color & Taste & Aroma & Flavor & Appearance & $\begin{array}{l}\text { Overall } \\
\text { Acceptability }\end{array}$ \\
\hline $\mathbf{T}_{\mathbf{0}}$ & 8 & 7.5 & 7 & 6.75 & 7.5 & 7.35 \\
\hline $\mathbf{T}_{\mathbf{1}}$ & 7.5 & 7 & 7 & 7 & 7.75 & 7.25 \\
\hline $\mathbf{T}_{\mathbf{2}}$ & 7.5 & 7.5 & 6.75 & 7.25 & 7.75 & 7.35 \\
\hline $\mathbf{T}_{\mathbf{3}}$ & 8.75 & 8.25 & 8.75 & 8 & 9 & 8.55 \\
\hline $\mathbf{T}_{\mathbf{4}}$ & 7.5 & 6.75 & 7 & 7.75 & 7 & 7.2 \\
\hline $\mathbf{T}_{\mathbf{5}}$ & 6.75 & 6 & 6 & 7 & 7.25 & 6.6 \\
\hline
\end{tabular}


Microbial analysis of whey based pineapple Beverage

According to the food safety and standard act 2006, food products standards and food
Additives (REGN,2011) microbiological requirement of food products given limit for fruit beverage, the total plate count not more than $50 \mathrm{cfu} / \mathrm{ml}$ as well as yeast and mold count not more than $2.0 \mathrm{cfu} / \mathrm{ml}$.

Table.1 Thermal process schedule of whey-Pineapple beverage

\begin{tabular}{|c|c|}
\hline Pasteurization Temperature $\left({ }^{\circ} \mathrm{C}\right)$ & Time (Min) \\
\hline 75 & 15 \\
\hline 80 & 15 \\
\hline 85 & 15 \\
\hline 90 & 15 \\
\hline
\end{tabular}

Fig.1 Flow chart preparation of pineapple juice

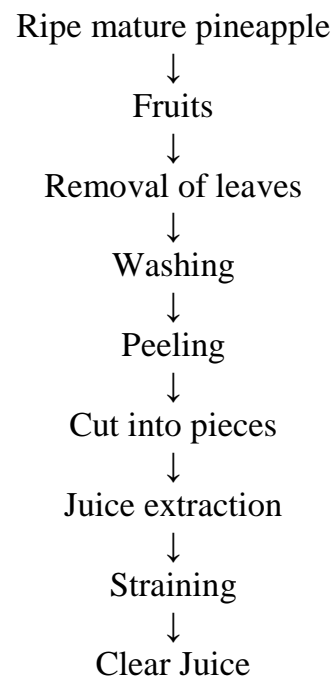

Fig.2 Flow chart for pretreatments of whey

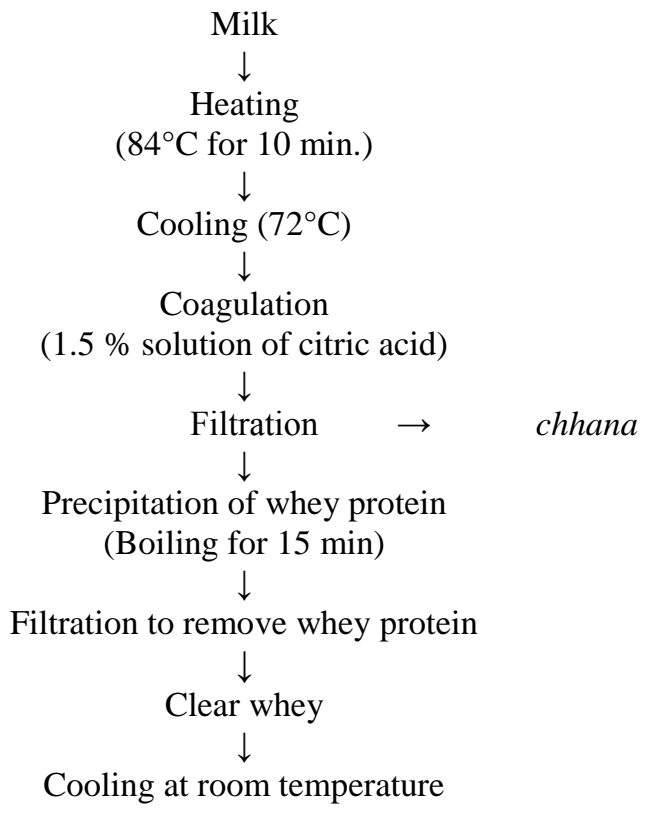


Fig.3 Flow chart for preparation of whey based pineapple beverage

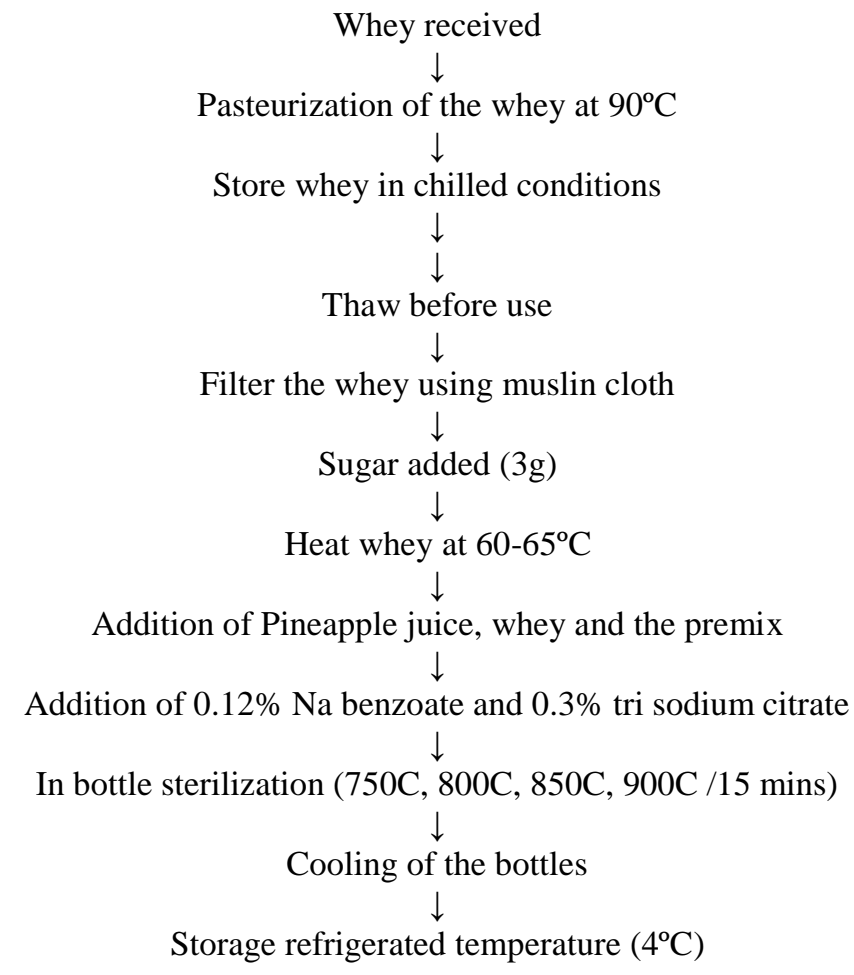

Fig.4

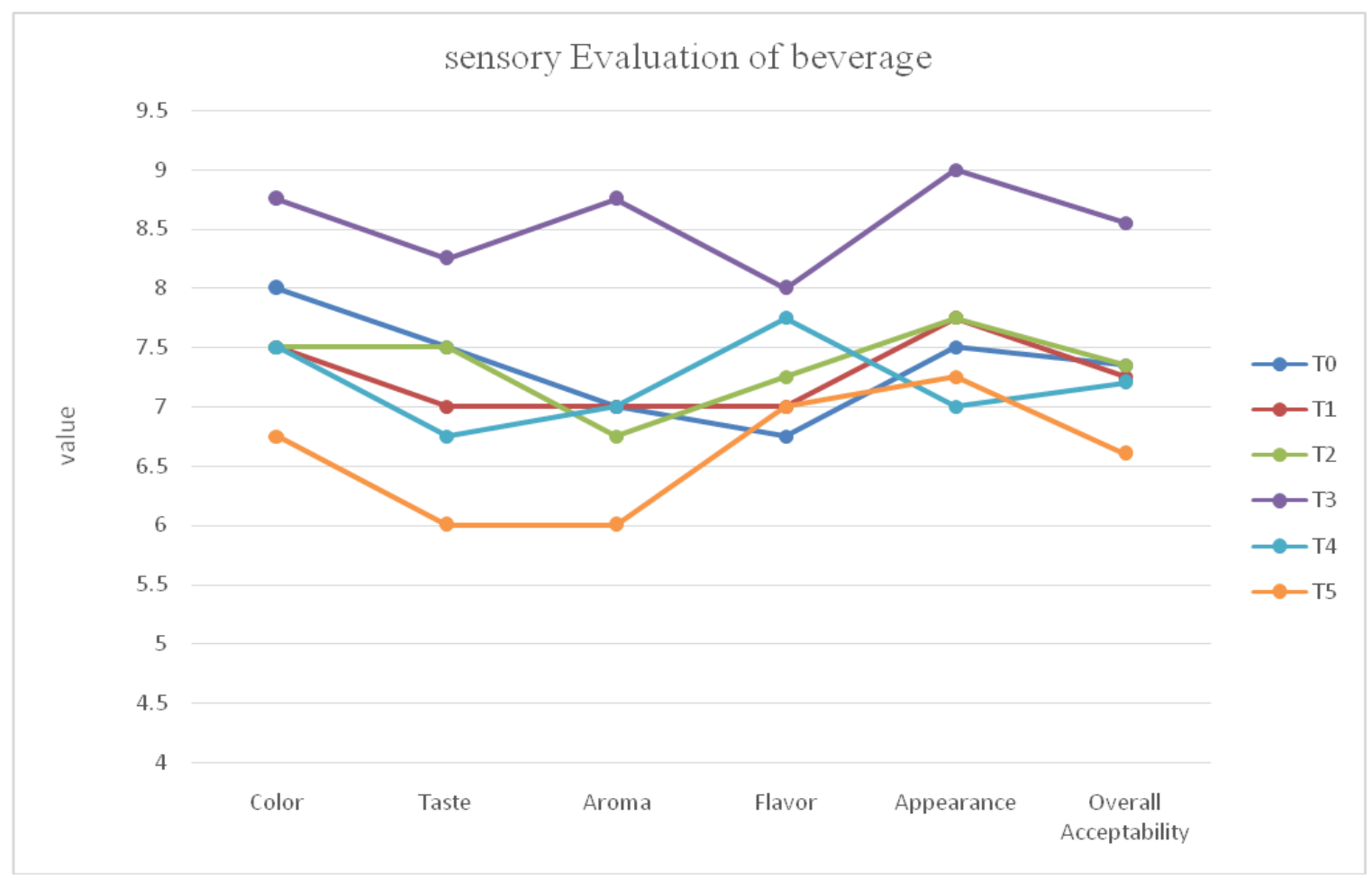




\section{Yeast and mold count}

During the microbiological study of Effect of thermal processing on preparation of Whey based pineapple beverage for 20 days of Shelf life, five samples were prepared for Yeast and Mold analysis i.e. $\mathrm{T}_{1}, \mathrm{~T}_{2}, \mathrm{~T}_{3}, \mathrm{~T}_{4}$ and $\mathrm{T}_{5}$ After first 10 days showed slight increase in there colony count. After the 15 days of shelf life study it was seen in sample there was increase in colony count and some sample showed less no of colony count. These treatments having the more shelf life than the other sample. Similar results were reported by Deka and Sethi (2001).

\begin{tabular}{|c|c|c|c|c|c|}
\hline Treatment & \multicolumn{5}{|c|}{ Yeast and Mold count } \\
\hline \multirow{2}{*}{ Sample No. } & \multirow{2}{*}{$\begin{array}{l}\text { Dilution } \\
\text { Qty. }\end{array}$} & \multirow{2}{*}{$\begin{array}{l}1 \mathrm{~g} / 9 \mathrm{ml} \\
\text { d.w }\end{array}$} & \multicolumn{3}{|c|}{ During storage period (Days) } \\
\hline & & & 10 Day & 15Day & 20Day \\
\hline $\mathbf{T}_{\mathbf{0}}$ & $1 \mathrm{ML}$ & $10^{-1}$ & 2 & 3 & 7 \\
\hline$T_{1}$ & $1 \mathrm{ML}$ & $10^{-2}$ & 2 & 3 & 5 \\
\hline $\mathbf{T}_{2}$ & $1 \mathrm{ML}$ & $10^{-3}$ & 3 & 4 & 5 \\
\hline $\mathbf{T}_{3}$ & $1 \mathrm{ML}$ & $10^{-4}$ & 1 & 2 & 3 \\
\hline $\mathbf{T}_{4}$ & $1 \mathrm{ML}$ & $10^{-5}$ & 3 & 5 & 6 \\
\hline $\mathbf{T}_{5}$ & $1 \mathrm{ML}$ & $10^{-6}$ & 4 & 6 & 8 \\
\hline
\end{tabular}

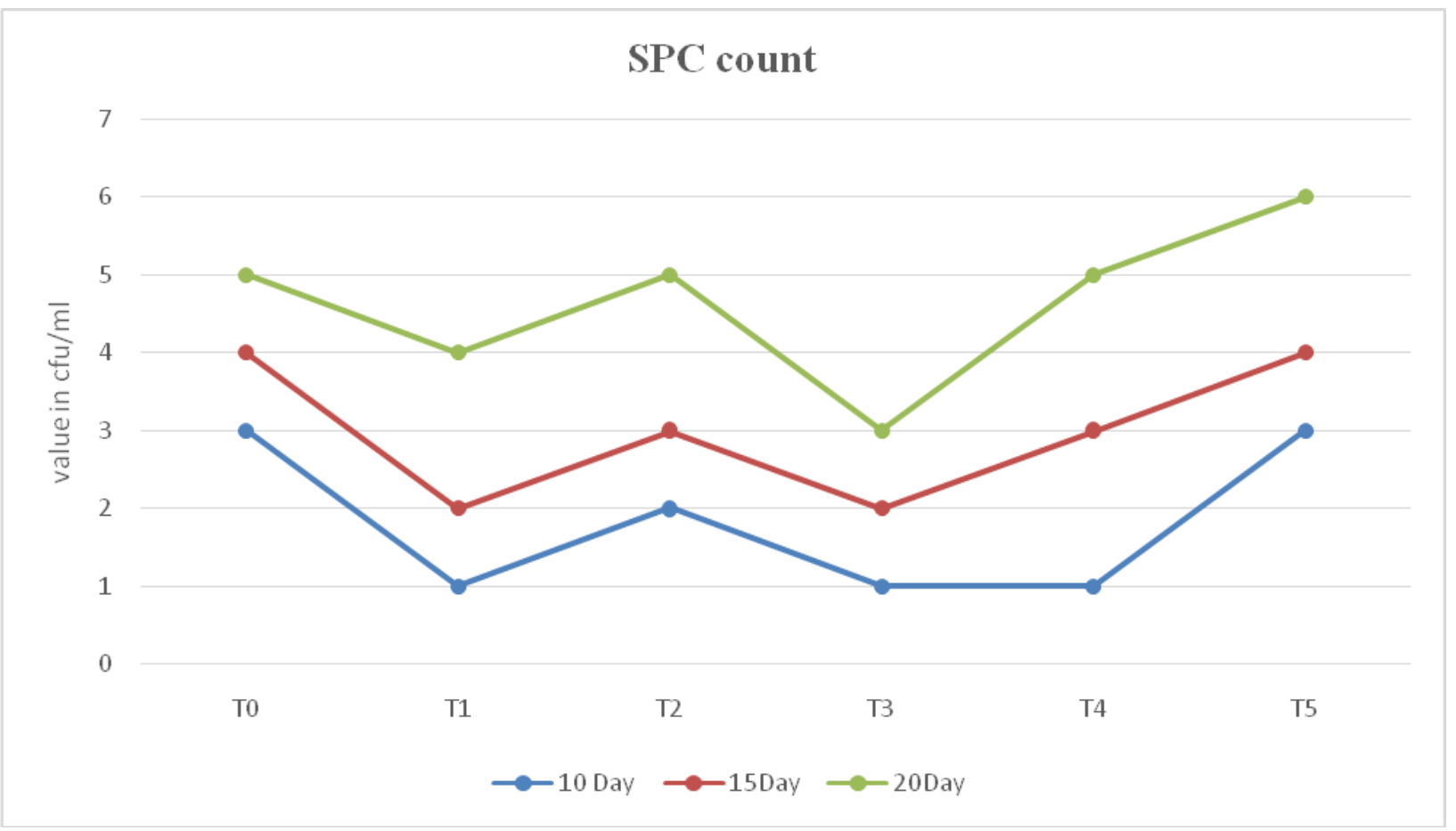

SPC count for whey based pineapple beverage

During the present study of Effect of thermal processing on preparation of Whey based Pineapple beverage for 20 days of shelf life, 6 sample were prepared for SPC count treatment i.e. $T_{0}, T_{1}, T_{2}, T_{3}, T_{4}$ and $T_{5}$ After 
first 10 days SPC count was found in each sample.

\begin{tabular}{|c|c|c|c|c|c|}
\hline No. Treatment & SPC count cfu & & & & \\
\hline \multirow[b]{2}{*}{ Sample No. } & \multirow[b]{2}{*}{ Dilution Qty. } & \multirow[b]{2}{*}{ 1g /9ml D.W } & \multicolumn{3}{|c|}{ During storage(Days) } \\
\hline & & & 10Day & 15Day & 20Day \\
\hline $\mathbf{T}_{\mathbf{0}}$ & $1 \mathrm{ML}$ & $10^{-3}$ & 3 & 4 & 5 \\
\hline $\mathbf{T}_{1}$ & $1 \mathrm{ML}$ & $10^{-3}$ & 1 & 2 & 4 \\
\hline $\mathbf{T}_{2}$ & $1 \mathrm{ML}$ & $10^{-3}$ & 2 & 3 & 5 \\
\hline $\mathbf{T}_{\mathbf{3}}$ & $1 \mathrm{ML}$ & $10^{-3}$ & 1 & 2 & 3 \\
\hline $\mathbf{T}_{4}$ & $1 \mathrm{ML}$ & $10^{-3}$ & 1 & 3 & 5 \\
\hline $\mathbf{T}_{5}$ & $1 \mathrm{ML}$ & $10^{-3}$ & 3 & 4 & 6 \\
\hline
\end{tabular}

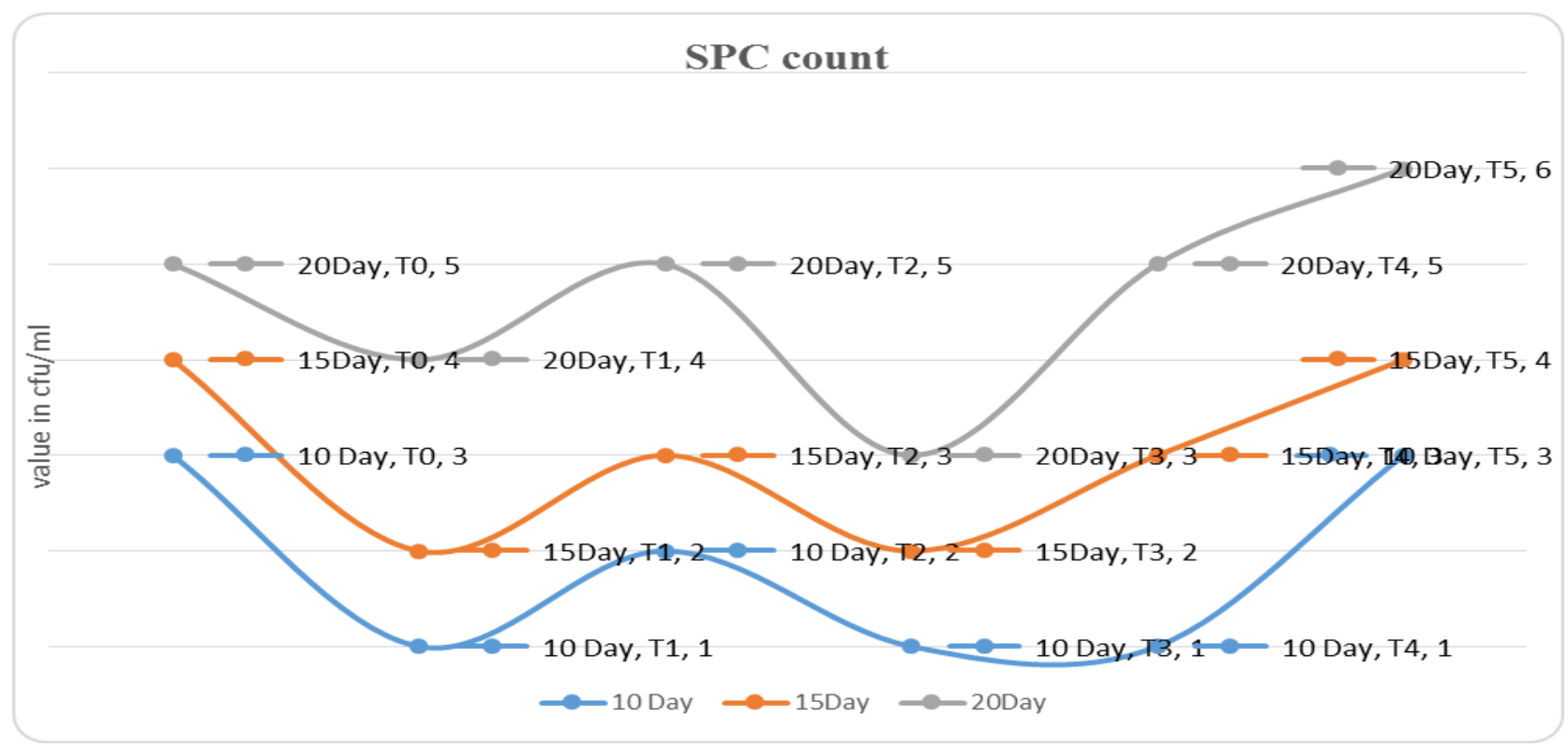

After 15 days of shelf life study in sample there was a slight increase in their colony count as compared to 10 days of shelf life. For next 20 days there was increase in the SPC count in control in some sample. The sample which was found less SPC count are more acceptable after 20 days of shelf life. Similar results were reported by Skrede (2000).

Summary and conclusion of the study are as follows:

It can be concluded that whey offers a good option for the production of functional pineapple beverages. Paneer whey based beverage showed better protein and mineral content than control and thus can help in countering protein energy malnutrition and mineral deficiency among children in developing countries. Use of paneer whey not only improved protein content of beverages, but showed highest mineral content among all the beverages suggesting use of paneer whey based beverage as an electrolytic drink. Paneer whey not only improved the shelf life and color of pineapple beverages, but also improved overall acceptability. Therefore whey is used for preparation of beverages as a water replacer. Pineapple juice is rich in 
vitamin and other nutraceuticals properties and both are used for preparation of whey based beverage. In beverage preparation sugar, sodium benzoate and tri sodium citrate were used respectively as sweetener, preservatives and buffering agent. Keeping above point in view, efforts have been made to develop the whey based pineapple beverage with the following objectives:

Manufacture of whey based pineapple beverages.

To study the effect thermal processing on physico-chemical and sensory characteristics of the fresh and stored beverage.

Effect of thermal processing on the sensory characteristics of fresh whey based pineapple beverage.

Microbial analysis of whey based pineapple Beverage.

Beverages prepared by taking whey, pineapple juice in different blending ratio of whey and pineapple juice for control and five different concentration of juice $(90,80,70,60$ and 50) with five different treatments T1, T2, T3, T4 and T5 respectively. Chhana whey was use to replace water partially. First whey was treated for heat precipitation of whey protein. Then whey was mixed with juice thoroughly with sugar (3g) and preservatives for each treatment. After thermal treatment $\left(75^{\circ} \mathrm{C}, 80^{\circ} \mathrm{C}, 85^{\circ} \mathrm{C}, 90^{\circ} \mathrm{C}\right)$ beverage were filled into sterilized glass bottles. The bottles were air cooled at room temperature and then stored at refrigerator temperature for a period of 20 days. The pineapple juice was analyzed for TSS, acidity, total sugar, $\mathrm{pH}$ and ascorbic acid. The fresh beverage samples were analyzed for TSS, total sugar, acidity, $\mathrm{pH}$, ascorbic acid and sensory characteristics. The shelf- life of beverages was evaluated up to 20 day of storage period at an interval of 10 days by microbial analysis. The changes in TSS, total sugar, acidity, $\mathrm{pH}$, ascorbic acid and sensory characteristics were determined at each stage. It was observed on physicochemical evaluation of prepared beverages that acidity increased while ascorbic acid decreased moreover TSS, $\mathrm{pH}$ and total sugar observed very little change during storage in case of all the treatments. On the basis of sensory evaluation, it was observed that beverage T3 (70:30) scored highest. The sensory scores and overall acceptability of beverages improved as the level of pineapple juice was increased from $60 \%$ to $70 \%$. For beverages containing $50 \%$ juice gives bitter in taste and hence the organoleptic scores are poor. During shelf life study of Effect of thermal processing on preparation of whey based pineapple beverage blended with whey and juice, microbial analysis of experimental sample were done i.e. $\mathrm{y} / \mathrm{m}, \mathrm{SPC}$ count for 20 days of shelf life.

In this present dissertation, whey based pineapple beverage were prepared by considering the nutritional and healthy aspects of both whey and pineapple juice. Blending was done as juice: whey ratios (100:0), (90:10), (80:20), (70:30), (60:40) and (50:50). Thermal treatment was given at $75^{\circ} \mathrm{C}, 80^{\circ} \mathrm{C}$, $85^{\circ} \mathrm{C}$ and $90^{\circ} \mathrm{C}$ for $15 \mathrm{~min}$. It was concluded that juice treated at $85^{\circ} \mathrm{C}$ for $15 \mathrm{~min}$ showed best results regarding the keeping as well as the nutritional quality of blended beverage. The sample T3 (70:30) treated at $85^{\circ} \mathrm{C}$ for 15 min was most effective beverage which showed TSS (14.39 brix), acidity (0.66 \%), vitamin C (5.42 $\mathrm{mg}$ ) and Sensory evaluation was also higher and better consistency score up to the end of storage. The population of bacteria is less, mold and yeast $(3 \times 103)$ at the end of storage 20 days. On the basis of above results revealed in the present study, it can be concluded that the formulation of whey based pineapple beverage is possible to satisfy consumer taste and preferences. The product was microbiologically safe during 20 days of storage with good acceptability. So this 
beverage could be stored for 20 days.

\section{References}

Anand J.C. (1970) Effect of pretreatments on the loss of Vitamin C. and tannins in Aonla preserve "Indian Fd. Packer", 24 (6): 16.

Akkinwale T.O. (2000) cashew apple juice. Its use in fortifying the nutritional quality of some tropical fruits. Europe food research technology vol.211:205-207

Agarwal S. and Chopra C.S. (2004) Studies on changes in ascorbic acid and total phenols in making aonla products. Beverage and Food World, 31(5), 32-33.

A.O.A.C. (1995). Official Methods of Analysis. 16th edn. Association of Official Analytical Chemists, Washington DC.

B.I.S. 1961. "IS: 1479, Part - II. Methods of Test for Dairy Industry. Chemical Analysis of Milk." New Delhi: BIS.

B.I.S. 1977. "IS: 1224, Part - II. Determination of fat by Gerbers method - Milk Products". New Delhi: BIS.

B.I.S. 1479 (part I), (1981) Methods of test for dairy Industry rapid examination of milk. Bereau of Indian Standards, ManakBhavan, New Delhi, India.

Baljeet, S.Y. Ritika, B.Y. and Sarita, R., et al., (2013). Studies on development and storage of whey-based pineapple (Ananas comosus) and bottle gourd (Lagenaria siceraria) mixed herbal beverage. International Food Research Journal 20(2): 607-612.

Barwal, V.S., Singh, T.K. and Alkesh.( 2005). Studies on processing and development of ready-to-serve drink from bittergourd fruit. Journal of Food Science and Technology 42(3): 217-220.

Blasco R., Esteve M.J., Frigola and M. Rodrigo (2004): Ascorbic acid degradation kinetics in mushrooms in a high temperature short time process controlled by a thermos resistance. Lebensm-wiss. U,-Technol, 37171_175.

Choudhary, P.L., Sandey, K.K. and Naik, Y.K. (2008). Whey based mango herbal (Cardamom) beverage. Dairy industry Conference organized by Institute of Agriculture science, Banaras Hindu
University, Varanasi. Feb. 19-21.

Deka B.C. and Sethi V. (2001). Preparation of mixed fruit juice spiced RTS beverages. Ind. Fd. Packer, 42(3): 58-61.

Gagrani, R.L., Rathi, S.D. and Ingle, U.M. (1987). Preparation of fruit flavoured beverage from whey. J. Food Sci. Technol., 24, March- April.

Kumar, S. and Manimegalai, G. (2005). Studies on storage stability of whey based papaya juice blended RTS beverage. J Food Sci. Technol., 42(2): 185-188.

Krishnaveni, A., Manimegalai G. and Saravanakumar, R. (2001). Storage stability of jack fruit (Artocarpus heterophyllus) RTS beverage. J. Food Sci. Technol,38(6): 601-602.

Murlidhar P. Ingale, Rahul C. Ranveer and Kalyan D. Nagargoje (2009). Development of whey based custard Apple (Annona squamosa L.) Beverage. Food technology division University of chemical Technology Ambedkar Marathwada university Aurangabad.

Naik, Y. K., Khare, A., Choudhary, P. L., Goel, B. K. and Shrivastava, A. (2009). Studies on Physico-chemical and Sensory Characteristics of Whey Based Watermelon Beverage. Asian J. Research Chem., 2(1):57-59.

Naik, Y. K., Khare, A., Choudhary, P. L., Goel, B. K. and Shrivastava, A. (2009). Studies on Physico-chemical and Sensory Characteristics of Whey Based Watermelon Beverage. Asian J. Research Chem., 2(1):57-59.

Patel, S., Prasanth S., Choudhary P. L. and Sahu C. (2007). Techno-economic Feasibility of Whey Based Mango Hebal (Ginger) Beverage. Indian J. Dairy Sci., 60(3):149155.

Pandey, A.K. and Singh, D.P. (2002). Shelf-life of carbonated soft beverage from Chhana whey. J. Dairying, Foods and Home Sci., 21(1): 36-39.

Pal, H., Banik, A.K. and Nuchhungi (2007). Effect of blending, additives and storage conditions on the quality of watermelon nectar. 2(1): 38-43.

Ranganna, S. 1986. Handbook of Analysis and Quality Control for Fruit and Vegetable 
Products. New Delhi: Tata McGraw-Hill Publishing Co. Ltd.

Ranganna, S. (2002). Handbook of Analysis and quality control for fruit and vegetable products. Tata McGraw Hill Publication, New Delhi.

Ritika, B. Y., Baljeet, S. Y. and Kalia, N. (2010). Development and Storage Studies on Whey-Based Banana Herbal (Mentha arvensis) Beverage. American J. of food Technol., 5(2): 121-129.

Sharma, H. P., Singh, S. K. and Sharma, R. (2010). Development of Mixed fruit Squash of Pineapple and Pomegranate. Beverage and Food World. 37(4):55-56.

Sahu, C. (2003). Technology for the preparation of whey based Mango Herbal (LG) Beverage. M. Tech., Agriculture processing and food Engineering, Thesis submitted to I.G.A.U. Raipur (C. G.).

Smithers, G. W., Ballard, F. J., Copeland, A. D., De Silva, K. J., de Dionysius, D. A., Francis, G. L., et al., (1996). New opportunities from the isolation and utilization of whey proteins. Journal of Dairy Science, 79(8), 1454-1459.

Sirohi, D., Patel S., Choudhary P.L. and Sahu C. (2005). Studies on preparation and storage of whey based mango herbal Pudina (Mentha arvensis) beverages. J. Food Sci. Technol., 42 (2):157-161.

Skrede G., Wrolstad R.E. and Durst R.W. (2000). Changes in anthocyanins and polyphenolic during juice processing of high bush blueberries (Vaccinium corymbosum L.). Journal of Food Science, 65, 357-364.

Suvimol C. and Pranee A. (2008.) Bioactive compounds and volatile compounds of Thai bael fruit (Aegle marmelos L.) Correa) as a valuable source for functional food ingredients. Int Food Res J 15(3): 1-9.

Srivastava R.P. and Srivastava R.K. (1964) Chemical composition of fresh and dried aonla,"Sci., Cult." 30 (9): 446.

Singh I.S. and Sanjeev K. (1995). Studies on processing of aonla fruits: II Aonla Products. Progs.Hort., 27(1/2):39-47.

Sagar V.S. and Khurdiya D.S. (1999) Studies on dehydration of Dashehari mango slices. Ind. Fd. Pack. 53:5-9.

Singh M.R., and Pathak J.A. (1987) Physicochemical composition of different cultivars of aonla. Ind. Fd. Pack. 41:7-10.

Tiwari R.B. (2000). Studies on blending of guava and papaya pulp for RTS beverages. Indian Food Packer, 54: 68.

Tandon D.K., and Yadav P.S. (2003) Effect of blanching and lye peeling on the quality of aonla candy. Indian Food Packer, 57(6), 147-152.

Tandon D.K., Kumar S., Dikshit A. and Shukla D.K. (2007). Storage study on bael-papaya blended RTS beverage. Indian Food Packer, 73: 9

Waqas N. Baba, Safoora Din, Hilal A. Punoo, Touseef A. Wani, Mudasir Ahmad and F. A. Masoodi. Comparison of cheese and paneer whey for production of a functional pineapple beverage: Nutraceutical properties and Shelf life. Association of Food Scientists and Technologists (India) Food Sci Technol.

Yadav, R.B., Yadav, B.S. and Kalia, N. 2010. Development and storage studies on wheybased banana herbal (Mentha arvensis) beverage. American Journal of Food Technology 5: 121-129.

\section{How to cite this article:}

Ashutosh Pandey, Atul Anand Mishra, R.N. Shukla, Praveen Kumar Dubey and Rahul Kumar Vasant. 2019. Development of the Process for Whey Based Pineapple Beverage. Int.J.Curr.Microbiol.App.Sci. 8(06): 3212-3228. doi: https://doi.org/10.20546/ijcmas.2019.806.383 